Editorial

\title{
Guest Editorial: Conservation Tillage for Organic Farming
}

\author{
Patrick M. Carr \\ Central Agricultural Research Center, Montana State University, 52583 U.S. Highway 87, Moccasin, \\ MT 59462-9512, USA; patrick.carr@montana.edu \\ Academic Editor: Les Copeland \\ Received: 1 March 2017; Accepted: 2 March 2017; Published: 7 March 2017
}

\begin{abstract}
There is interest in reducing or even eliminating tillage in organic production systems. In this special Issue, research teams in Europe and North America summarize recent and on-going efforts to develop conservation-tillage systems that can be used on commercial organic farms. While progress is being made in the development of organic no-tillage (no-till) systems, considerable work still needs to be done before there will be wide-spread adoption by organic farmers.
\end{abstract}

Keywords: conservation tillage; cover crops; no-till; reduced-tillage; organic; organic no-till; regenerative agriculture

Tillage has, and continues to be, widely used for weed control on organic farms globally, in spite of the deleterious impacts that tilling the soil can have on aggregation [1,2], biology [3-6], erosivity [7,8], and other ecosystem services $[9,10]$. This reliance on tillage has led some to openly criticize organic farming proponents as advocating for an agro-ecological system that is not sustainable [11,12]. Recognizing the negative impacts that tillage can have on soil quality, Creamer et al. [13] and others $[14,15]$ worked on alternative weed control systems that did not rely on tillage or herbicides, beginning in the 1990s. Cover crops were a key component in these no-tillage (no-till) systems because of the vegetative mulch that could be produced when these crops were killed. This vegetative mulch proved effective at suppressing weeds when retained on the soil surface, as long as amounts of dry matter exceeded 5000 to $6000 \mathrm{~kg} \cdot \mathrm{ha}^{-1}$ [16].

Different kill methods for terminating cover crops were compared in early organic no-till research, but most involved rolling or mowing [13-15]. Over time, interest focused on rollers with blunt blades welded or otherwise connected to the rollers in various configurations [17]. The blades crushed or crimped the cover crops while being rolled, enhancing kill and speeding desiccation of the vegetative mulch. A breakthrough came when an effective "roller-crimper" was built and tested in the eastern USA. Using this implement, organic maize (Zea mays L.) following rolled-crimped hairy vetch (Vicia villosa Roth) and soybean (Glycine max L.) following rolled-crimped cereal rye (Secale cereale L.) cover crops reportedly could be grown profitably in the U.S. mid-Atlantic region without tillage [18].

Research teams throughout North America attempted to reproduce the success in growing organic crops without tillage that was described by Moyer [18]. Efforts also were made to grow other cash crops using organic no-till practices in addition to maize and soybean. A summary of this effort was described in several papers published in the March 2012, issue of the Journal of Renewable Agriculture and Food Systems [19-27]. Some research teams reported success, particularly when soybean and wheat (Triticum spp.) were planted directly into the vegetative mulch created by rolled-crimped cover crops $[23,24,26]$. Others were able to grow some cash crops with little difficulty but encountered weed, nutrient deficiency, and other challenges when other cash crops were grown [22,25]. Still other teams encountered numerous challenges and were unable to grow cash crops successfully without 
tillage [21]. Soil moisture deficits, weed infestations, and nutrient deficiencies were just a few of the problems identified by the researchers unable to grow some cash crops under no-till management in some environments [21,22].

Researchers have continued to work on organic no-till systems since the group of papers was published in the Journal of Renewable Agriculture and Food Systems [28-31]. A decision was made to follow-up this previous effort with a new set of papers summarizing the current state of knowledge regarding organic no-till farming. With this came a desire to expand the discussion beyond Europe and North America, where all of the previous research had been focused [19-27]. Contacts were made with researchers and organic farming organizations working on, or having an interest in, organic no-till systems in Australia, Africa, Asia, and South America, as well as those in Europe and North America. It was learned that while interest in organic no-till is indeed global, much of the work outside of Europe and North America has not advanced to the level where it is publishable. In contrast, research groups in Europe and North America continue to make important contributions to the literature [32-34].

The papers included in this issue of Agriculture represent some, but not all, of the researchers and research teams working on organic no-till. While not all individuals and groups contributed papers, results of their research are cited in the papers that are included. As such, the papers in this issue of Agriculture are fairly inclusive of the research that has been, or soon-will be, published on organic no-till in Europe and North America. It is hoped that these papers will be helpful to those dedicated to the development of organic no-till systems that are environmentally sustainable.

Vincent-Cabloud et al. [35] summarize the current status of organic no-till research and commercial practice in France, as well as across Europe. They describe how variations in climate impact farmer knowledge of, and experience with, no-till farming methods, and how well primed European organic farmers might be to adopting or expanding no-till practices on their farms. For example, over $50 \%$ of interviewed organic farmers in southern Europe had some experience with no-till because of the soil-water conservation benefits that resulted, whereas fewer than $25 \%$ of northern European organic farmers had similar experience, in part because practices that conserve soil water are not beneficial and may create problems in cool humid regions. Conversely, most organic farmers in northern Europe grew cover crops while fewer than $50 \%$ of southern European organic farmers did so because of concerns that soil-water deficits would result after they were grown. Overall, adoption of no-till practices remains low among organic farmers in Europe because of an inability to suppress weeds, a lack of knowledge in how to implement cover crop-based no-till farming as practiced in North America, and a general lack of manufacturers of equipment developed for no-till environments in Europe.

The focus of the paper by Zikeli and Gruber [36] is on the status of organic conservation-tillage in Germany. The authors point out that few, if any, German organic farmers or researchers have worked, or are working, with no-till systems where cash crops are planted directly into rolled-crimped cover crop mulch like the systems being studied in North America. Rather, German emphasis is on reducing tillage so that it is less aggressive and not done as frequently. While the moldboard plow remains a popular and widely used tillage implement on German farms, non-inversion tillage using chisel plows is becoming more widely practiced. Similarly, roto-tillers and other implements that limit soil disturbance to shallow depths are being used. Adoption of conservation-tillage practices is correlated to farm size, with reduced-tillage systems being more likely on larger farms. These farms, in turn, are more prevalent in eastern parts of the country due to the agrarian structure in the former GDR where large agricultural cooperatives and crop specialization were emphasized. Perceived benefits in soil quality resulting from the adoption of conservation-tillage explains much of the interest in reduced-tillage practices among German organic farmers. At the same time, soil fertility concerns and lack of adequate weed control are major impediments to adoption of conservation-tillage and particularly no-till practices on organic farms.

Weber et al. [37] summarizes results of a small-plot study in Germany where organic soybean was grown in conventional- or clean-till, reduced-till, and no-till systems at two locations during both 2014 and 2015. Barley (Hordeum vulgare L.) and rye cover crops were rolled and crimped prior to 
planting soybean in no-till plots, and mowed with above-ground biomass removed in reduced-till plots. No cover crops were planted in the conventional-till plots. Soybean yield averaged $1.1 \mathrm{t} \cdot \mathrm{ha}^{-1}$ in no-till plots compared with $2.0 \mathrm{t} \cdot \mathrm{ha}^{-1}$ in conventional-till and $1.5 \mathrm{t} \cdot \mathrm{ha}^{-1}$ in reduced-till plots. In some instances, weed density was greater in no-till than conventional- and reduced-till plots. Problems also were encountered when planting soybean directly into the killed cover-crop mulch in no-till plots, sometimes resulting in a lower plant density under no-till than either tilled system. Weber et al. [37] conclude that current no-till equipment in Germany is not suitable for planting soybean and other cash crops directly into the thick vegetative mulch created by rolled-crimped cover crops.

Lehnof et al. [38] point out the challenges faced by researchers working on organic no-till systems in the North American Great Plains and other semi-arid regions. Many of the obstacles revolve around the limited water which is available to wheat and other cash crops grown in these regions. Anything which can exacerbate the water-stress conditions that typically develop-such as cover crops using too much stored soil-water before being killed-will likely not be adopted by organic farmers. Unfortunately, cover crops must reach advanced growth stages when rolled-crimped or mowed so that a thick weed-suppressive mulch is produced, but soil water can be depleted in the process. Moreover, Canada thistle (Cirsium arvense L. Scop.), field bindweed (Convolvulus arvensis L.), and dandelion (Taraxacum officinale Weber) are serious problems in the Great Plains region, and these and other perennial weeds will likely not be controlled by a vegetative mulch, regardless of the thickness. Lehnof et al. [38] argue for the integration, or re-introduction, of livestock onto the cropping systems landscape. They describe an on-going study where sheep (Ovis aries) are used to graze strategically and, because of this, have eliminated tillage during a 36-month period of a longer 5 -year (60-month) rotation. Interestingly, while weed density was 11 times greater when growing lentil (Lens culinaris Medik) in the rotational no-till system compared with a tilled organic system during 2016 , grain yield was only reduced by $21 \%$, suggesting a non-proportionate relationship between weed pressure and crop yield in organic no-till systems.

Wallace et al. [39] report that no-till production of soybean is a viable alternative to conventional production of soybean in tilled systems for organic farmers in the mid-Atlantic region of the USA. Thus far, challenges relating to fertility management prevent similar progress in the development of viable organic no-till maize production systems in this region. As reported by others [38], the organic no-till systems described by Wallace et al. [39] include both no-till (e.g., soybean) and tilled (e.g., wheat) crop phases. Furthermore, inter-row, high-residue cultivars are being considered for the control of perennial weeds and for overall weed control in years where cover crop performance is sub-optimal during 'no-till' crop phases, disqualifying these systems from no-till status though they would continue to qualify as conservation-tillage systems. Wallace et al. [39] identify problems still to be solved using these systems, in spite of the progress that has been made, particularly when growing soybean. Echoing the concern of others [35,37], Wallace et al. [39] indicate that improvements in planter design are needed to enhance cash crop establishment in seedbeds covered with a thick cover crop mulch. More research is needed on the use of high-residue cultivators in these systems and how that interacts with the amount of cover crop mulch needed to suppress weed growth. Questions remain on how to use a roller-crimper so that consistent high-kill rates result when attempting to terminate cover crops. Improved cover crop germplasm is needed for use in organic rotational no-till systems, as is a better understanding of how these systems impact soil health.

Halde et al. [40] echo some of the concerns expressed by others about organic no-till, including limitations in cover crop germplasm [39], increased and sometimes excessive weed pressure [35,36,38], and cash yield depression [37], among others. Halde et al. [40] point out that considerable research has been conducted on organic no-till in eastern Canada, but most of this is published in French in technical reports rather than in peer-reviewed scientific journals. Others $[26,35]$ note language barriers and similar challenges which prevent the free-flow of information between organic no-till researchers, limiting the progress being made on developing systems that can be adopted by organic farmers. Halde et al. [40] indicate that organic no-till continues to generate interest in eastern Canada, 
particularly among conventional no-till farmers interested in transitioning to organic production methods. Inconsistent weed control as well as cash crop yield depression continue to be major drawbacks which prevent the adoption of no-till by organic farmers in eastern Canada. Research is underway on using bio-herbicides rather than roller-crimpers to kill cover crops.

Silva and Delate [41] report considerable success in the organic no-till production of soybean in the U.S. Midwest. Midwestern organic farmers are adopting no-till practices when growing soybean, in part because of research demonstrating the viability of the rotational organic no-till approach in Iowa and Wisconsin $[25,30]$. Organic no-till production of maize remains a risky venture for farmers in this region, largely because of problems surrounding the hairy vetch cover crop that precedes the no-till maize crop phase. Alternatives to hairy vetch are needed to make a no-till maize crop phase viable. Also needed are improvements to equipment used in organic no-till production systems.

Conflicts of Interest: The author declares no conflict of interest.

\section{References}

1. Beare, M.H.; Hendrix, P.F.; Coleman, D.C. Water-stable aggregates and organic matter fractions in conventional- and no-tillage soils. Soil Sci. Soc. Am. J. 1994, 58, 777-786. [CrossRef]

2. Six, J.; Elliott, E.T.; Paustian, K. Aggregate and soil organic matter dynamics under conventional and no-tillage systems. Soil Sci. Soc. Am. J. 1999, 63, 1350-1358. [CrossRef]

3. Grandy, A.S.; Robertson, G.P.; Thelen, K.D. Do productivity and environmental trade-off justify periodically cultivating no-till cropping systems. Agron. J. 2006, 98, 1377-1383. [CrossRef]

4. Karlen, D.L.; Wollenhaupt, N.C.; Erbach, D.C.; Berry, E.C.; Swan, J.B.; Eash, N.S.; Jordahl, J.L. Long-term tillage effects on soil quality. Soil Tillage Res. 1994, 32, 313-327. [CrossRef]

5. Wortmann, C.S.; Quincke, A.; Drijber, R.A.; Mamo, M.; Franti, T. Soil microbial community change and recovery after one- time tillage of continuous no-till. Agron. J. 2008, 100, 1681-1686. [CrossRef]

6. Frey, S.D.; Elliott, E.T.; Paustian, K. Bacterial and fungal abundance and biomass in conventional and no-tillage agroecosystems along two climatic gradients. Soil Biol. Biochem. 1999, 31, 573-585. [CrossRef]

7. Lal, R.; Reicosky, D.C.; Hanson, J.D. Evolution of the plow over 10,000 years and the rationale for no-till farming. Soil Tillage Res. 2007, 93, 1-12. [CrossRef]

8. Triplett, G.B., Jr.; Dick, W.A. No-tillage crop production: A revolution in agriculture! Agron. J. 2008, 100, S153-S165. [CrossRef]

9. Hanson, N.C.; Allen, B.L.; Baumhardt, R.L.; Lyon, D.J. Research achievements and adoption of no-till, dryland cropping in the semi-arid U.S. Great Plains. Field Crops Res. 2012, 132, 196-203. [CrossRef]

10. McLaughlin, A.; Mineau, P. The impact of agricultural practices on biodiversity. Agric. Ecosyst. Environ. 1995, 55, 201-212. [CrossRef]

11. Trewavas, A. A critical assessment of organic farming-and-food assertions with particular respect to the UK and the potential environmental benefits of no-till agriculture. Crop Protect. 2004, 23, 757-781. [CrossRef]

12. Leifeld, J. How sustainable is organic farming? Agric. Ecosyst. Environ. 2012, 150, 121-122. [CrossRef]

13. Creamer, N.G.; Plassman, B.; Benett, M.A.; Wood, R.K.; Stinner, B.R.; Cardina, J. A method for mechanically killing cover crops to optimize weed suppression 1995. Am. J. Altern. Agric. 1995, 10, 157-162. [CrossRef]

14. Creamer, N.G.; Dabney, S.M. Killing cover crops mechanically: Review of recent literature and assessment of new research results. Am. J. Altern. Agric. 2002, 17, 32-40.

15. Ashford, D.L.; Reeves, W.D. Use of a mechanical roller crimper as an alternative kill method for cover crops. Am. J. Altern. Agric. 2003, 18, 37-45. [CrossRef]

16. Teasdale, J.R. Contribution of cover crops to weed management in sustainable agriculture systems. J. Prod. Agric. 1996, 9, 475-479. [CrossRef]

17. Kornecki, T.S.; Price, A.J.; Raper, R.L.; Arriaga, F.J. New roller crimper concepts for mechanical termination of cover crops in conservation agriculture. Renew. Agric. Food Syst. 2009, 24, 165-173. [CrossRef]

18. Moyer, J. Organic No-Till Farming; Acres USA: Austin, TX, USA, 2010; p. 204. 
19. Carr, P.M.; Mäder, P.; Creamer, N.G.; Beeby, J.S. Editorial: Overview and comparison of conservation tillage practices and organic farming in Europe and North America. Renew. Agric. Food Syst. 2012, 27, 2-6. [CrossRef]

20. Mäder, P.; Berner, A. Development of reduced tillage systems in organic farming in Europe. Renew. Agric. Food Syst. 2012, 27, 7-11. [CrossRef]

21. Carr, P.M.; Anderson, R.L.; Lawley, Y.E.; Miller, P.R.; Zwinger, S.F. Organic zero-till in the northern US Great Plains Region: Opportunities and obstacles. Renew. Agric. Food Syst. 2012, 27, 12-20. [CrossRef]

22. Luna, J.M.; Mitchell, J.P.; Shrestha, A. Conservation tillage for organic agriculture: Evolution toward hybrid systems in the western USA. Renew. Agric. Food Syst. 2012, 27, 21-30. [CrossRef]

23. Mirsky, S.B.; Ryan, M.R.; Curran, W.S.; Teasdale, J.R.; Maul, J.; Spargo, J.T.; Moyer, J.; Grantham, A.M.; Weber, D.; Way, T.R.; et al. Conservation tillage issues: Cover crop-based organic rotational no-till grain production in the mid-Atlantic region, USA. Renew. Agric. Food syst. 2012, 27, 31-40. [CrossRef]

24. Reberg-Horton, S.C.; Grossman, J.M.; Kornecki, T.S.; Meijer, A.D.; Price, A.J.; Place, G.T.; Webster, T.M. Utilizing cover crop mulches to reduce tillage in organic systems in the southeastern USA. Renew. Agric. Food Syst. 2012, 27, 41-48. [CrossRef]

25. Delate, K.; Cwach, D.; Chase, C. Organic no-tillage system effects on soybean, corn and irrigated tomato production and economic performance in Iowa, USA. Renew. Agric. Food Syst. 2012, 27, 49-59. [CrossRef]

26. Shirtliffe, S.J.; Johnson, E.N. Progress towards no-till organic weed control in western Canada. Renew. Agric. Food Syst. 2012, 27, 60-67. [CrossRef]

27. Gadermaier, F.; Berner, A.; Fließbach, A.; Friede, J.K.; Mäder, P. Impact of reduced tillage on soil organic carbon and nutrient budgets under organic farming. Agric. Food Syst. 2012, 27, 68-80. [CrossRef]

28. Carr, P.M.; Horsley, R.D.; Gunderson, J.J.; Winch, T.J.; Martin, G.B. Weed growth and crop performance following hairy vetch, rye, and wheat cover crops in a cool semiarid region. Org. Agric. 2013. [CrossRef]

29. Halde, C.; Gulden, R.H.; Entz, M.H. Selecting cover crop mulches for organic rotational no-till systems in Manitoba, Canada. Agron. J. 2014, 106, 1193-1204. [CrossRef]

30. Silva, E.M. Screening five fall-sown cover crops for use in organic no-till crop production in the upper Midwest. Agroecol. Sustain. Food Syst. 2014, 38, 748-763. [CrossRef]

31. Wells, M.S.; Reberg-Horton, S.C.; Smith, A.N.; Grossman, J.M. The reduction of plant-available nitrogen by cover crop mulches and subsequent effects on soybean performance and weed interference. Agron. J. 2013, 105, 539-545. [CrossRef]

32. Mirsky, S.B.; Ackroyd, V.J.; Cordeau, S.; Curran, W.S.; Hashemi, M.; Reberg-Horton, S.C.; Ryan, M.R. Hairy vetch biomass across the eastern US: Effects of latitude, seeding rate and date, and termination timing. Agron. J. 2017, in press.

33. Peigné, J.; Lefevre, V.; Vian, J.F.; Fleury, P. Conservation Agriculture in Organic Farming: Experiences, Challenges and Opportunities in Europe. In Conservation Agriculture; Farooq, M., Siddique, K.H.M., Eds.; Springer International Publishing: Gewerbestrasse, Switzerland, 2015; pp. 559-578.

34. Halde, C.; Bamford, K.C.; Entz, M.H. Crop agronomic performance under a six-year continuous organic no-till system and other tilled and conventionally-managed systems in the northern Great Plains of Canada. Agric. Ecosyst. Environ. 2015, 213, 121-130. [CrossRef]

35. Vincent-Caboud, L.; Peigné, J.; Casagrande, M.; Silva, E. Overview of organic cover crop-based no tillage techniques in Europe: Farmer practices and research challenges. Agriculture 2017, in press.

36. Zikeli, S.; Gruber, S. Reduced Tillage and No-Till in Organic Farming Systems, Germany-Status Quo, Potentials and Challenges. Agriculture 2017, in press.

37. Weber, J.F.; Kunz, C.; Peteinatos, G.G.; Zikeli, S.; Gerhards, R. Weed efficacy of conventional tillage, no-tillage and cover crops in organic soybean. Agriculture 2017, in press.

38. Lehnhoff, E.; Miller, Z.; Miller, P.; Johnson, S.; Scott, T.; Hatfield, P.; Menalled, F.D. Organic agriculture and the quest for the holy grail in water-limited ecosystems: 1 managing weeds and reducing tillage intensity. Agriculture 2017, in press.

39. Wallace, J.M.; Williams, A.; Liebert, J.A.; Ackroyd, V.J.; Vann, R.A.; Curran, W.S.; Keene, C.L.; VanGesse, M.J.; Ryan, M.R.; Mirsky, S.B. Cover crop-based, organic rotational no-till corn and soybean production systems in the mid-Atlantic United States. Agriculture 2017, in press. 
40. Halde, C.; Gagné, S.; Charles, A.; Lawley, Y. Organic no-till systems in eastern Canada: A review. Agriculture 2017, in press.

41. Silva, E.M.; Delate, K. A decade of progress in organic cover crop based reduced tillage practices in the Upper Midwestern US. Agriculture 2017, in press. 